\title{
Pengaruh Kualitas Produk, Harga, Promosi terhadap Kepuasan Konsumen Minyak Angin V-Fresh Aromatheraphy pada PT. Eagle Indo Pharma
}

\author{
Chelsa Audi Mahira, Lamtota Togatorop, Simon Ginting*, Jessica Apriani Simbolon, \\ Juniarlina Sianipar, Fenny Krisna Marpaung \\ Universitas Prima Indonesia, jl Sekip, Petisah Tengah, Kota Medan \\ ${ }^{*}$ Correspondence email: simoniting@gmail.com
}

\begin{abstract}
Abstrak. Hasil pengujian hipotesis menunjukkan bahwa secara parsial diketahui untuk variabel kualitas produk adalah $2,967$. Karena t hitung 2,967 > t tabel 1,98, maka dapat disimpulkan $\mathrm{H}_{\mathrm{a}}$ diterima dan $\mathrm{H}_{0}$ ditolak. Secara parsial untuk variabel harga adalah 4,087. Karena $\mathrm{t}$ hitung 4,087 $>\mathrm{t}$ tabel 1,98, maka dapat disimpulkan $\mathrm{H}_{\mathrm{a}}$ diterima dan $\mathrm{H}_{0}$ ditolak. Secara parsial untuk variabel promosi adalah 0,943. Karena t hitung 0,943< $\mathrm{t}$ tabel 1,98, maka dapat disimpulkan $\mathrm{H}_{0}$ diterima dan $\mathrm{H}_{\mathrm{a}}$ ditolak. Untuk hasil uji F diperoleh hasil nilai Sig < 0,05 yaitu sebesar 0,000. Maka hipotesis diterima atau kualitas produk (X1), harga (X2) dan promosi (X3) secara simultan berpengaruh terhadap kepuasan konsumen (Y).
\end{abstract}

Kata kunci: Kualitas produk; Harga; Promosi dan Kepuasan konsumen

Abstract. The results of hypothesis testing show that partially known for the product quality variable is 2,967. Because $t$ count $2,967>t$ table 1.98 , it can be concluded that $H_{a}$ is accepted and $H_{0}$ is rejected. Partially for the price variable is 4.087. Because $t$ count $4.087>t$ table 1.98 , it can be concluded that $H_{a}$ is accepted and $H_{0}$ is rejected. Partially for the promotion variable is 0,943. Because $t$ count 0,943 < t table 1.98, it can be concluded that $H_{0}$ is accepted and $H_{a}$ is rejected. For the results of the $F$ test, it was obtained that the Sig <0.05 was 0.000. Then the hypothesis is accepted or product quality (X1), price (X2) and promotion (X3) simultaneously have an effect on customer satisfaction (Y).

Keywords: product quality; price; promotion and customer satisfaction

\section{PENDAHULUAN}

Dampak dari perubahan teknologi dapat menuntut perusahaan untuk lebih inovatif dalam memperbaharui dan menciptakan produknya, Produk yang di ciptakan semuanya saling berkaitan untuk memberi kepuasan pada konsumen, produk tidak hanya inovatif tetapi juga kualitasnya harus bagus dan tidak membuat konsumen kecewa.

Kualitas adalah salah satu aspek yang paling penting dalam sebuah produk. Dengan kualitas yang terjamin maka kepuasaan konsumen akan meningkat untuk sebuah produk kita dan dengan kualitas yang terjamin kita semakin berani untuk bersaing dengan produk lain karena semakin baik kualitas produk kita maka peluang keberhasilan produk kita di pasaran akan semakin besar.

Harga menjadi aspek yang paling penting di tahap terakhir karena harga akan menentukan minat dan kepuasaan konsumen untuk membeli suatu produk tersebut. jika konsumen merasa produk tidak sesuai dengan harga maka kecil kemungkinan produk kita akan lancar di pasaran. dengan harga yang tidak sesuai atau di luar kemampuan para konsumen maka produk kita akan gagal untuk bersaing dengan produk yang lain.

Promosi sangat berperan penting dalam keberhasilan suatu produk di pasaran. Di zaman yang modern ini banyak konsumen menilai barang dari sebuah promosi, baik promosi di tv, sosial media ataupun media lainya. Iklan menjadi salah satu strategi promosi yang seringkali digunakan oleh perusahaan dalam mempromosikan produknya baik itu produk baru atau produk lama. Maka dari itu PT. Eagle Indo Pharma selaku produsen Minyak Angin V-fresh Aromatheraphy merancang strategi promosi dengan membuat dan menayangkan iklan di televisi yang diharapkan dapat membuat minat beli konsumen.

\section{Pengertian Kualitas Produk}

Menurut Abdurrahman (2015), kualitas produk adalah salah satu sarana positioning utama pemasar. Menurut Setiyaningrum et.al (2015), kualitas produk adalah suatu atribut fisik, psikis, jasa dan simbolik yang dibuat untuk memuaskan kebutuhan dan keinginan pelanggan. Menurut Abdullah dan Tantri (2012), kualitas produk adalah kemampuan produk untuk melaksanakan fungsinya. Menurut peneliti terdahulu Michelle (2018), kualitas produk merupakan keawetan, ketahanan suatu produk dalam melaksankan fungsinya dalam memenuhi kebutuhan konsumen pada jangka waktu tertentu. Menurut peneliti terdahulu Andika (2019), kualitas produk adalah produk yang dihasilkan oleh produsen dalam rangka memenuhi kebutuhan dan keinginan serta kepuasaan seluruh konsumen yang membeli ataupun yang memakai produk tersebut.

\section{Pengertian Harga}

Menurut Abdurrahman (2015), harga adalah sejumlah uang yang berfungsi sebagai alat tukar untuk 
memperoleh produk atau jasa. Menurut Kotler dan Amstrong (2012) mendefenisikan harga sebagai sejumlah uang yang di minta untuk suatu produk atau suatu jasa. Menurut Alma (2016), harga adalah nilai suatu barang yang dinyatakan dengan uang. Menurut peneliti terdahulu Ernita (2018), harga adalah suatu nilai yang di tukarkan oleh konsumen untuk memperoleh barang atau jasa yang mereka inginkan, atau juga dapat diartikan penentuan nilai suatu produk di benak konsumen. Menurut peneliti terdahulu Morgan (2018), harga merupakan jumlah uang yang dibutuhkan agar memperoleh hak kepemilikan atau penggunaan suatu barang atau jasa.

\section{Pengertian Promosi}

Menurut Alma (2016), promosi adalah sejenis komunikasi yang memberi penjelasan yang meyakinkan calon konsumen tentang barang dan jasa. Menurut Setiyaningrum et al (2015), promosi adalah salah satu elemen bauran pemsaran sebuah perusahaan. Menurut Abdurrahman (2015), promosi adalah satu bauran pemasaran yang digunakan untuk meningkatkan nilai pelanggan atau membangun ekuitas merek dalam ingatan pelanggan. Menurut peneliti terdahulu Morgan (2018), promosi penjualan merupakan kegiatan promosi yang dapat mengubah perilaku pembelian konsumen dengan segera dan merangsang respon konsumen berupa perilaku.

\section{Pengertian Kepuasan Konsumen}

Menurut Kotler dan Keller (2017), kepuasan konsumen adalah perasaan senang atau kecewa yang di miliki seseorang berdasarkan perbandingan antara kenyataan yang di peroleh dengan harapan yang dimiliki oleh konsumen. Menurut Abdullah dan Tantri (2014), kepuasan pelanggan adalah hasil yang dirasakan pembeli dari kinerja perusahaan yang mmenuhi harapan mereka. (Zeithaml dan Bitner, 2013)

\section{Teori Pengaruh Kualitas Produk Terhadap Kepuasan Konsumen}

Kualitas produk sangat berpengaruh dengan nilai dan kepuasaan pelanggan. Jika kualitas V-fresh bagus maka kepuasan konsumen akan meningkat. dan minat beli konsumen pun akan meningkat.

\section{Teori Pengaruh Harga Terhadap Kepuasan Konsumen}

Harga mempunyai pengaruh langsung bagi laba perusahaan. Harga juga mempunyai peran utama dalam menciptakan nilai pelanggan dan membangun hubungan dengan pelanggan. Penyesuain harga akan sangat menentukan minat dan kepuasan konsumen terhadap harga untuk membeli produk tersebut.

\section{Teori Pengaruh Promosi Terhadap Kepuasan Konsumen}

Promosi berpengaruh signifikan terhadap keputusan pembelian. Semakin tinggi dan menariknya promosi yang dilakukan oleh perusahaan, maka akan semakin sering konsumen dalam melakukan pembelian.

\section{Teori Pengaruh Kualitas Produk, Harga, Promosi Terhadap Kepuasan Konsumen}

Kualitas produk yang terjamin sangat berpengaruh terhadap nilai dan kepuasan pelanggan, dengan harga yang terjangkau akan meningkatkan minat beli konsumen, dan promosi yang bagus dan menarik akan berpengaruh signifikan terhadap keputusan pembelian konsumen.

\section{METODE \\ Jenis Penelitian}

Jenis penelitian ini adalah deskriptif. Menurut sugiyono (2016), penelitian deskriptif adalah penelitian yang digunakan untuk menganalisa data dengan cara mendeskripsikan atau menggambarkan data yang telah terkumpul sebagaimana adanya tanpa bermaksud membuat kesimpulan yang berlaku untuk umum atau generalisasi.

\section{Populasi}

Menurut Sugiyono (2016) populasi adalah wilayah generalisasi yang terdiri dari obyek/subyek yang mempunyai kualitas atau karakteristik tertentu yang ditetapkan oleh peneliti untuk dipelajari dan kemudian ditarik kesimpulan. Adapun populasi dalam penelitian ini adalah konsumen akhir (pengguna) Minyak Angin VFresh Aromatheraphy di Kecamatan Medan Perjuangan dengan penduduk kelompok umur 25-34 sebanyak 13.767 jiwa pada tahun 2018.

\section{Sampel}

Menurut Sugiyono (2016) sampel adalah bagian dari jumlah dan karateristik yang dimiliki oleh populasi tersebut. Dalam peneletian ini si peneliti menggunakan rumus Slovin $n=\frac{\mathbb{N}}{1+\mathbb{N e} e^{2}}$ untuk menentukan jumlah sample. Jumlah sample yang didapat dari rumus slovin dengan margin error adalah $10 \%$ maka didapatkan hasil sebanyak 100.

Metode pengambilan sample dalam penelitian ini menggunakan metode probability sampling dengan cara penarikan acak sederhana (Simpel Random Sampling).

\section{HASIL DAN PEMBAHASAN} Analisis Statistik Deskriptif 
Chelsa Audi Mahira, Lamtota Togatorop, Simon Ginting, Jessica Apriani Simbolon, Juniarlina Sianipar, Fenny Krisna Marpaung, Pengaruh Kualitas Produk, Harga, Promosi terhadap Kepuasan Konsumen Minyak Angin V-Fresh Aromatheraphy pada PT. Eagle Indo Pharma

Tabel 1. Hasil Uji Statistik Deskriptif

\begin{tabular}{|l|r|r|r|r|r|}
\hline \multicolumn{7}{|c|}{ Descriptive Statistics } \\
\hline & N & Minimum & Maximum & Mean & $\begin{array}{c}\text { Std. } \\
\text { Deviation }\end{array}$ \\
\hline Kualitas produk & 100 & 20 & 29 & 23.61 & 1.687 \\
\hline Harga & 100 & 10 & 19 & 15.62 & 2.019 \\
\hline Rammosi & 100 & 15 & 30 & 22.68 & 3.467 \\
\hline $\begin{array}{l}\text { Kepuasan } \\
\text { konsumen }\end{array}$ & 100 & 14 & 29 & 23.46 & 2.508 \\
\hline $\begin{array}{l}\text { Valid N } \\
\text { (listwise) }\end{array}$ & 100 & & & & \\
\hline
\end{tabular}

Sumber: data diolah

\section{Hasil Uji Asumsi Klasik \\ Uji Normalitas}

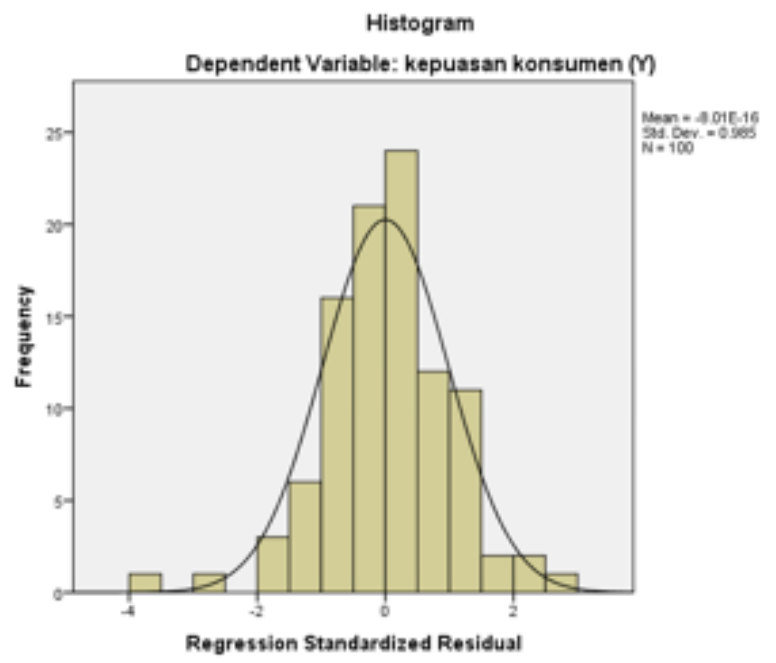

Gambar 1. Uji Normalitas Histogram

Dilihat dari gambar diatas data didalam garis melengkung yang membentuk seperti lonceng terbalik, data tertinggi berada padi garis melengkung sejajar diantara angka 0.

\section{Normal P.P Plot of Regression Standardized Residual}

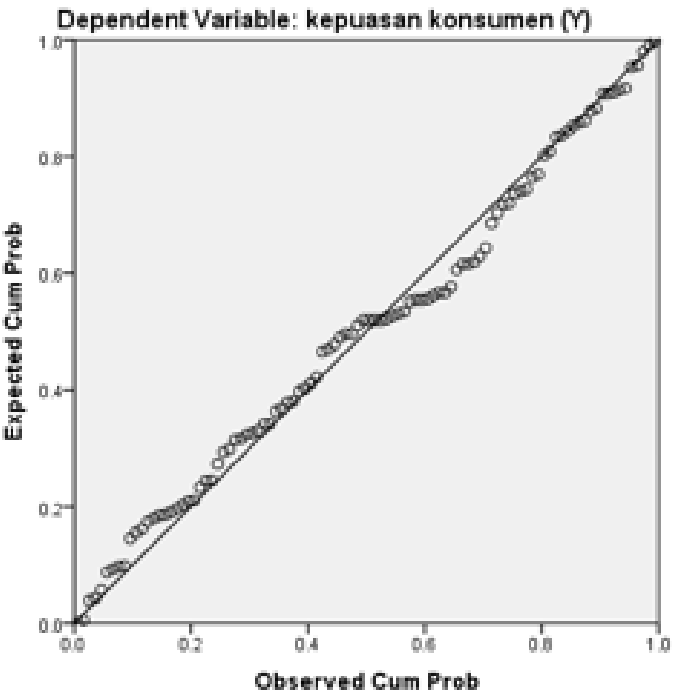

Gambar 2. Uji Normalitas P-P Plot
Dilihat dari gambar diatas data dapat dikatakan normal karena penyebaran datanya mengikuti garis diagonalnya.

\section{Uji Statistik}

Tabel 2. Hasil Uji Kolmogorov-smirnov (K-S)

\begin{tabular}{|l|l|r|}
\hline \multicolumn{2}{|c|}{ One-Sample Kolmogorov-Smirnov Test } \\
\hline \multicolumn{2}{|c|}{} & $\begin{array}{r}\text { Unstandardiz } \\
\text { ed Residual }\end{array}$ \\
\hline $\mathrm{N}$ & Mean & .0000000 \\
\hline \multirow{2}{*}{ Normal Parametersa,b } & $\begin{array}{l}\text { Std. } \\
\text { Deviation }\end{array}$ & 1.85181603 \\
\hline Most Extreme Differences & Absolute & .073 \\
\cline { 2 - 3 } & Positive & .073 \\
\cline { 2 - 3 } & Negative & -.052 \\
\hline Test Statistic & .073 \\
\hline Asymp. Sig. (2-tailed) & .200 c,d \\
\hline a. Test distribution is Normal. \\
\hline b. Calculated from data. \\
\hline c. Lilliefors Significance Correction. \\
\hline d. This is a lower bound of the true significance. \\
\hline
\end{tabular}

Sumber: data diolah

Dari tabel diatas dapat disimpulkan bahwa data dalam penelitian ini dinyatakan normal karena Sig > 0.05 yaitu sebesar 0.200 .

\section{Uji Multikolinearitas}

Uji multikolonieritas bertujuan untuk menguji apakah model regresi korelasi antar variabel bebas (independen). Jika nilai tolerance $>0,10$ atau sama dengan nilai $\mathrm{VIF}<10$ maka tidak terjadi korelasi antar variabel bebas (independen) (Ghozali, 2016).

Tabel 3. Hasil Uji Multikolonieritas

\begin{tabular}{|c|c|c|c|c|c|c|c|}
\hline \multicolumn{8}{|c|}{ Coefficients ${ }^{\mathrm{a}}$} \\
\hline \multirow[t]{2}{*}{ Model } & \multicolumn{2}{|c|}{$\begin{array}{l}\text { Unstandardize } \\
\text { d Coefficients }\end{array}$} & \multirow{2}{*}{$\begin{array}{c}\begin{array}{c}\text { Standar } \\
\text { dized } \\
\text { Coeffici } \\
\text { ents }\end{array} \\
\text { Beta }\end{array}$} & \multirow[t]{2}{*}{$\mathrm{t}$} & \multirow[t]{2}{*}{ Sig. } & \multicolumn{2}{|c|}{$\begin{array}{l}\text { Collinearity } \\
\text { Statistics }\end{array}$} \\
\hline & B & $\begin{array}{c}\text { Std. } \\
\text { Erro } \\
\text { r }\end{array}$ & & & & $\begin{array}{l}\text { Toler } \\
\text { ance }\end{array}$ & VIF \\
\hline 1 (Constant) & 4.220 & $\begin{array}{r}2.66 \\
5\end{array}$ & & 1.583 & .117 & & \\
\hline $\begin{array}{l}\text { kualitas produk } \\
\text { (x1) }\end{array}$ & .402 & .135 & .270 & 2.967 & .004 & .684 & 1.463 \\
\hline harga $(x 2)$ & .522 & .128 & .420 & 4.087 & .000 & .537 & 1.864 \\
\hline promosi (x3) & .070 & .074 & .097 & .943 & .348 & .537 & 1.863 \\
\hline
\end{tabular}

Sumber: data diolah

Hasil yang diperoleh dari tabel di atas adalah nilai tolerance $>0,10$ dan nilai $\mathrm{VIF}<10$.

\section{Uji Heteroskedastisitas}

Uji heteroskedastisitas bertujuan menguji apakah dalam model regresi terjadi ketidaksamaan variance dari 
Chelsa Audi Mahira, Lamtota Togatorop, Simon Ginting, Jessica Apriani Simbolon, Juniarlina Sianipar, Fenny Krisna Marpaung, Pengaruh Kualitas Produk, Harga, Promosi terhadap Kepuasan Konsumen Minyak Angin V-Fresh Aromatheraphy pada PT. Eagle Indo Pharma

residual satu pengamatan ke pengamatan yang lain. Cara untuk mendeteksi ada atau tidaknya heteroskedastitas yaitu dengan uji glesjer dan gambar scatterplot.

Tabel 4. Hasil Uji Glesjer

\begin{tabular}{|c|c|c|c|c|c|c|}
\hline \multicolumn{7}{|c|}{ Coefficients ${ }^{\mathrm{a}}$} \\
\hline \multirow{2}{*}{\multicolumn{2}{|c|}{ Model }} & \multicolumn{2}{|c|}{$\begin{array}{l}\text { Unstandardized } \\
\text { Coefficients }\end{array}$} & \multirow{3}{*}{$\begin{array}{c}\text { Standardized } \\
\text { Coefficients } \\
\text { Beta }\end{array}$} & \multirow{3}{*}{$\begin{array}{c}t^{t} \\
\\
2.497\end{array}$} & \multirow{3}{*}{$\begin{array}{l}\text { Sig. } \\
\\
.01 \\
\end{array}$} \\
\hline & & & \multirow{2}{*}{$\begin{array}{c}\begin{array}{c}\text { Std. } \\
\text { Error }\end{array} \\
1.707 \\
\end{array}$} & & & \\
\hline 1 & (Constant) & & & & & \\
\hline & kualitas produk $(\mathrm{x} 1)$ & -.030 & .087 & -.041 & -346 & .730 \\
\hline & barca $(x 2)$ & -.152 & .082 & -.250 & -1.860 & .066 \\
\hline & promosil $(x 3)$ & .009 & .048 & .025 & .188 & .851 \\
\hline
\end{tabular}

Sumber: data diolah

Dari tabel diatas diketahui nilai sig kualitas produk sebesar 0,730 , nilai sig harga sebesar 0,066 , nilai sig promosi sebesar 0,851 dapat disimpulkan tidak terjadi gejala heteroskedastisitas karena nilai sig> 0,05.

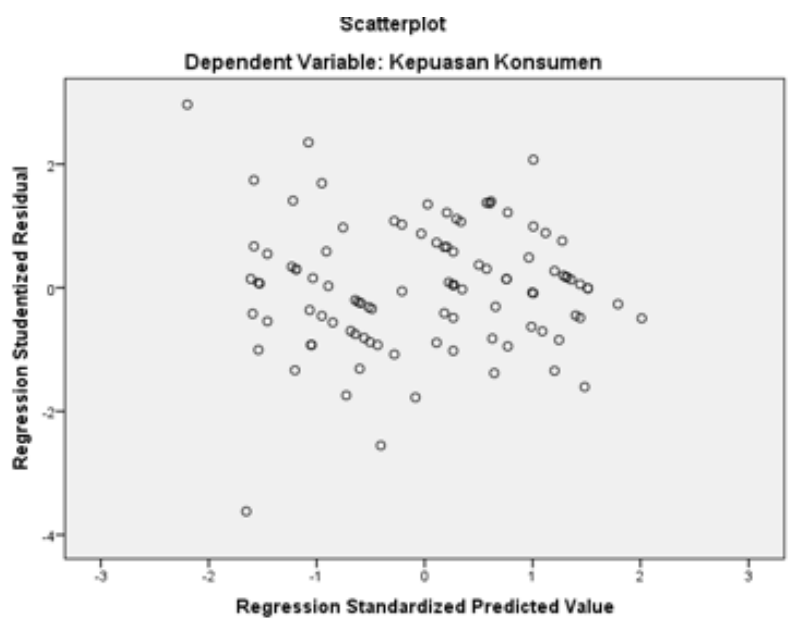

Gambar 3. Gambar Scatterplots

Kriteria uji yaitu :

1. Titik-titik data penyebaran di atas dan di bawah atau di sekitar angka 0 .

2. titik-titik tidak mengumpul hanya di atas atau dibawah saja.

3. Penyebaran titik-titik data tidak boleh membentuk pola bergelombang melebar kemudian menyempit dan melebar kembali.

4. Penyebaran titik-titik data tidak berpola.

Dari gambar scatterplots diatas dapat disimpulkan tidak terjadi gejala heteroskedastisitas karena memenuhi kriteria pengujian.

\section{Koefisien Determinasi ( $\mathbf{R}^{2}$ )}

Koefisien determinasi bertujuan untuk mengukur seberapa jauh kemampuan model dalam menerapkan variasi variabel dependen. Nilai koefisien determinasi adalah antara nol dan satu.
Tabel 4. Koefisien Determinasi $\left(\mathrm{R}^{2}\right)$

\begin{tabular}{|l|c|c|c|c|}
\hline \multicolumn{5}{|c|}{ Model Summary } \\
\hline $\begin{array}{l}\text { Mod } \\
\text { el }\end{array}$ & $\mathrm{R}$ & R Square & $\begin{array}{c}\text { Adjusted R } \\
\text { Square }\end{array}$ & $\begin{array}{c}\text { Std. Error of the } \\
\text { Estimate }\end{array}$ \\
\hline 1 & $.674^{\mathrm{a}}$ & .455 & .438 & 1.881 \\
\hline \multicolumn{5}{|l|}{$\begin{array}{l}\text { a. Predictors: (Constant), promosi (x3), kualitas produk (x1), harga } \\
\text { (x2) }\end{array}$} \\
\hline
\end{tabular}

Sumber: data diolah

Besarnya angka koefisien determinasi ( $\mathrm{R}$ square) adalah 0,455 atau sama dengan 45,5\%. Angka tersebut mengendung arti bahwa variabel kualitas (X1), variabel harga (X2) dan variabel promosi (X3) secara simultan berpengaruh terhadap variabel Kepuasan (Y) sebesar $45,5 \%$. Sedangkan sisanya $(100 \%-45,5 \%=54,5 \%)$ dipengaruhi oleh variabel yang tidak diteliti.

\section{Pengujian Hipotesis Secara Simultan (Uji F)}

Uji statistik F yaitu pengaruh simultan yang pada dasarnya digunakan untuk mengetahui apakah variabel independen secara bersama-sama atau simultan mempengaruhi variabel dependen. Dasar pengambilan keputusan dalam (UJI F), jika nilai Sig. < 0,05 hipotesis diterima. Maka artinya kualitas produk (X1), harga (X2) dan promosi (X3) secara simultan berpengaruh terhadap kepuasan konsumen $(\mathrm{Y})$.

Tabel 5. Hasil Uji F

\begin{tabular}{|c|c|c|c|c|c|c|}
\hline \multicolumn{7}{|c|}{ ANQVA } \\
\hline \multicolumn{2}{|c|}{ Model } & Sum of & df & Mean & $\mathrm{F}$ & Sig. \\
\hline \multirow[t]{3}{*}{1} & Regression & 283.347 & 3 & 94.449 & 26.708 & $.000^{b}$ \\
\hline & Residual & 339.493 & 96 & 3.536 & & \\
\hline & Total & 622.840 & 99 & & & \\
\hline \multicolumn{7}{|c|}{ a. Dependent Variable: kepuasan konsumen $(\mathrm{Y})$} \\
\hline \multicolumn{7}{|c|}{ b. Predictors: (Constant), promosi ( $x 3$ ), kualitas produk ( $x 1)$, harga $(x 2)$} \\
\hline
\end{tabular}

b. Predictors: (Constant), promosi (x3), kualitas produk (x1), harga $(\mathrm{x} 2)$

Sumber: data diolah

Dari table diatas diperoleh hasil nilai Sig $<0,05$ yaitu sebesar 0,000. Maka hipotesis diterima atau kualitas produk (X1), harga (X2) dan promosi (X3) secara simultan berpengaruh terhadap kepuasan konsumen $(\mathrm{Y})$

\section{Pengujian Hipotesis secara parsial (Uji t )}

Uji statistik t pada dasarnya menunjukan seberapa jauh pengaruh satu variabel independen secara individual dalam menerangkan variasi variabel dependen. Hipotesis :

$\mathrm{H}_{0}: \mathrm{X} 1=0$ (artinya variabel dependen tersebut bukan menunjukkan seberapa jauh pengaruh satu variabel penjelas/ independen secara individual dalam menerangkan variasi variabel dependen). 
Untuk mengetahui apakah hipotesis yang diajukan diterima atau ditolak, nilai $\mathrm{t}_{\text {hitung }}$ akan dibandingkan dengan $\mathrm{t}_{\text {tabel }}$ pada tingkat kepercayaan 95\% $(\alpha=0,05)$. Kriteria pengambilan keputusannya adalah : $\mathrm{H}_{0}$ diterima dan $\mathrm{H}_{\mathrm{a}}$ ditolak jika nilai $-\mathrm{t}_{\text {tabel }} \leq \mathrm{t}_{\text {hitung }} \leq \mathrm{t}_{\text {tabel }}$ pada $\alpha=0.05$.

$\mathrm{H}_{\mathrm{a}}$ diterima dan $\mathrm{H}_{0}$ ditolak jika nilai $-\mathrm{t}_{\text {hitung }}<-\mathrm{t}_{\text {tabel }}$ atau $\mathrm{t}_{\text {hitung }}>\mathrm{t}_{\text {tabel }}$ pada $\alpha=\mathrm{s} 0.05$.

Tabel 6. Hasil Uji t

\begin{tabular}{|c|c|c|c|c|c|c|}
\hline \multicolumn{7}{|c|}{ ANQVA } \\
\hline \multicolumn{2}{|c|}{ Model } & \multirow{2}{*}{$\begin{array}{r}\begin{array}{c}\text { Sum of } \\
\text { Squares }\end{array} \\
283.347\end{array}$} & \multirow{2}{*}{$\begin{array}{r}\text { df } \\
3 \\
\end{array}$} & \multirow{2}{*}{$\begin{array}{l}\begin{array}{l}\text { Mean } \\
\text { Square }\end{array} \\
94.449\end{array}$} & \multirow{2}{*}{$\begin{array}{c}F \\
26.708 \\
\end{array}$} & \multirow{2}{*}{$\begin{array}{r}\text { Sig. } \\
.000 \\
\end{array}$} \\
\hline 1 & Regression & & & & & \\
\hline & Residual & 339.493 & 96 & 3.536 & & \\
\hline & Total & 622.840 & 99 & & & \\
\hline \multicolumn{7}{|c|}{ a. Dependent Variable: kepuasan konsumen $(Y)$} \\
\hline & ctors: (Consta & romosi (x3), k & s. Drodu & ), barga $(x 2)$ & & \\
\hline
\end{tabular}

Sumber: data diolah

Berdasarkan tabel diatas diketahui nilai t hitung variabel kualitas adalah 2,96. Karena t hitung 2,967> t tabel 1,98, maka dapat disimpulkan $\mathrm{H}_{\mathrm{a}}$ diterima dan $\mathrm{H}_{0}$ ditolak. Nilai t hitung Variabel harga adalah 4,087. Karena t hitung 4,087 > t tabel 1,98, maka dapat disimpulkan $\mathrm{H}_{\mathrm{a}}$ diterima dan $\mathrm{H}_{0}$ ditolak. Nilai t hitung variabel promosi adalah 2,820. Karena t hitung 0,943 < t tabel 1,98, maka dapat disimpulkan $\mathrm{H}_{0}$ diterima dan $\mathrm{H}_{\mathrm{a}}$ ditolak.

\section{Pembahasan}

Pada uji validitas $r$ tabel untuk $n=30$ dan $\alpha=0,05$ adalah 0,361. Dari tabel 3.1 uji validitas dapat dilihat bahwa seluruh kuesioner dinyatakan valid karena $r$ hitung $>\mathrm{r}$ tabel. Pada pengujian reabilitas yang dilakukan dengan SPSS maka di cronbach's alpha $>$ 0,70 , dimana cronbach's alpha pada penelitian ini adalah 0,877 .

Dari tabel hasil uji statistik deskriptif jawaban responden diketahui jumlah responden $(\mathrm{N})$ sebesar 100, dari 100 responden, nilai minimum kualitas produk sebesar 20, nilai minimum harga sebesar 10, nilai minimum promosi sebesar 15 , nilai minimum kepuasan sebesar 14, nilai maximum kualitas produk sebesar 29, nilai maximum harga sebesar 19 , nilai maximum promosi sebesar 30, nilai maximum kepuasan sebesar 29 , nilai mean kualitas produk sebesar 23.61, nilai mean harga sebesar 15.62 , nilai mean promosi sebesar 22.68, dan nilai mean kepuasan sebesar 23.46.

Uji asumsi klasik terdiri dari tiga bagian yaitu uji normalitas, uji multikolonieritas, dan uji heteroskedastisitas. Uji normalitas dilakukan dengan melihat grafik histogram, gambar P-P plot dan non parametric statistic uji Kolmogorov smirnov dari ketiga kriteria uji dapat disimpulkan data berdistribusi normal. Uji multikolonieritas bertujuan untuk mengetahui korelasi antar variabel bebas dimana $\mathrm{VIF}=1 /$ tolerance . Nilai tolerance kualitas produk $>0,10$ yaitu 0,684 , nilai tolerance harga $>0,10$ yaitu 0,537 , nilai tolerance promosi $>0,10$ yaitu 0,537 . Nilai VIF kualitas produk $<$ 10 yaitu 1,463 , nilai VIF harga $<10$ yaitu 1,864 , nilai VIF promosi < 10 yaitu 1,863. Sedangkan uji Heterokedastisitas dilakukan dengan gambar scatterplot dimana pada gambar titik-titik data diatas dan dibawah atau sekitar angka 0 , titik-titik tidak hanya mengumpul diatas atau dibawah, penyebaran titik-titik data tidak boleh membentuk pola bergelombang melebar kemudian menyempit dan melebar kembali, dan penyebaran titiktitik tidak berpola.

Koefisien determinasi $\left(\mathrm{R}^{2}\right)$ dilakukan untuk mengetahui seberapa jauh kemampuan model dalam menerapkan variasi variabel dependen. Besarnya angka koefisien determinasi $\left(R^{2}\right)$ yaitu 0,455 atau sama dengan $45,5 \%$. Menunjukkan bahwa variabel kualitas produk (X1), variabel harga (X2), promosi (X3) secara simultan berpengaruh terhadap variabel kepuasan konsumen $(\mathrm{Y})$ sebesar 45,5\%. Sedangkan sisanya $(100 \%-45,5 \%=$ $54,5 \%)$ dipengaruhi oleh variabel yang tidak diteleiti. Pengujian Hipotesis Secara Simultan (Uji F) dilakukan untuk mengetahui apakah variabel independen secara bersama-sama atau simultan mempengaruhi variabel dependen. Dasar pengambilan keputusan dalam (UJI F), jika nilai Sig. < 0,05 hipotesis diterima. Dari hasil uji $\mathrm{F}$ diatas diperoleh nilai Sig < 0,05 yaitu sebesar 0,000. Maka hipotesis diterima atau kualitas produk (X1), harga (X2) dan promosi (X3) secara simultan berpengaruh terhadap kepuasan konsumen (Y). Pengujian Hipotesis secara parsial (Uji t ) Uji t dilakukan untuk menunjukkan seberapa jauh pengaruh satu variabel independen secara individual dalam menerangkan variasi variabel dependen. Berdasarkan hasil uji t diatas diperoleh nilai t hitung variabel kualitas adalah 2,967. Karena t hitung 2,967 > t tabel 1,98, maka dapat disimpulkan $\mathrm{H}_{\mathrm{a}}$ diterima dan $\mathrm{H}_{0}$ ditolak. Nilai t hitung Variabel harga adalah 4,087. Karena t hitung 4,138 $>$ t tabel 1,98, maka dapat disimpulkan $\mathrm{H}_{\mathrm{a}}$ diterima dan $\mathrm{H}_{0}$ ditolak. Nilai t hitung variabel promosi adalah 0,943 . Karena t hitung $0,943<\mathrm{t}$ tabel 1,98, maka dapat disimpulkan $\mathrm{H}_{0}$ diterima dan $\mathrm{H}_{\mathrm{a}}$ ditolak.

\section{SIMPULAN}

Berdasarkan hasil penelitian dapat diambil kesimpulan mengenai kualitas produk, harga dan promosi terhadap kepuasan konsumen Minyak Angin Vfresh Aromatheraphy Pada PT. Eagle Indo Pharma sebagai berikut:

1. Kualitas produk secara parsial berpengaruh positif dan signifikan terhadap kepuasan konsumen Minyak Angin V-fresh Aromatheraphy Pada PT. Eagle Indo Pharma.

2. Harga secara parsial berpengaruh positif dan signifikan terhadap kepuasan konsumen Minyak Angin V-fresh Aromatheraphy Pada PT. Eagle Indo Pharma. 
3. Promosi secara parsial berpengaruh positif terhadap kepuasan konsumen terhadap Minyak Angin V-fresh Aromatheraphy Pada PT. Eagle Indo Pharma.

4. Kualitas produk, Harga dan Promosi secara simultan berpengaruh positif dan signifikan terhadap kepuasan konsumen Minyak Angin V-fresh Aromatheraphy Pada PT. Eagle Indo Pharma.

\section{DAFTAR PUSTAKA}

Abdullah, Tantri. 2012 "Manajemen Pemasaran". PT. Raja Grafindo Persada: Jakarta

Abdurrahman. 2015. "Manajemen Strategi Pemasaran". Pustaka Setia: Bandung.

Alma 2016. "Manajemen Pemasaran Dan Pemasaran Jasa". Alfabeta: Bandung.

Andika. 2019 "Pengaruh Kualitas Produk Dan Harga Terhadap Kepuasan Pelanggan Pada PT. Metro". Jurnal Fakultas Ekonomi. Universitas Prima Indonesia Medan 2019.

Ernita. 2018 "Pengaruh Merek Dan Harga Terhadap Keputusan Pembelian Produk Asuransi Jiwa Pada PT.Prudential Life Assurance Cabang Jl. H. Adam Malik Medan. " Jurnal Fakultas Ekonomi. Universitas Prima Indonesia Medan 2018.

Ghozali. 2016. "Aplikasi Analisis Multivariete dengan program IBM SPSS 23". Badan Penerbit Universitas Diponegoro: Semarang.

Kotler, Amstrong. 2012 "Manajemen Pemasaran". Jakarta : Erlangga.

Kotler, Keller. 2017 "Manajemen Pemasaran" edisi 13. Erlangga: Jakarta.

Michelle. 2018. "Pengaruh Kualitas Produk Dan Citra Merek Terhadap Kepuasan Pembelian Beton Merek Merah Putih Pada PT. Karsa Prima Permata Nusa Medan" Jurnal Fakultas Ekonomi. Universitas Prima Indonesia Medan. 2018.

Morgan. 2018 "Pengaruh Harga Dan Promosi Penjualan Terhadap Keputusan Pembelian Produk Bakmi Mewah Pada PT. Inbisco Niagatama Semesta di Medan. "Jurnal Fakultas Ekonomi Universitas Prima Indonesia Medan 2018.

Setiyaningrum, Udaya, Efendi. 2015. "Prinsip-Prinsip Manajemen". Andi : yogyakarta.

Sugiono. 2016. "Metode Penelitian: Kuantitatif, Kualitatif, dan R\&D". Alfabeta : Bandung.

Zeithaml, V.A., M.J. Bitner, D.D. Gremler. 2013. Services Marketing: Integrating Customer Focus Across the Firm $6^{\text {th }} e d$. Mc.Graw-Hill. Boston. 